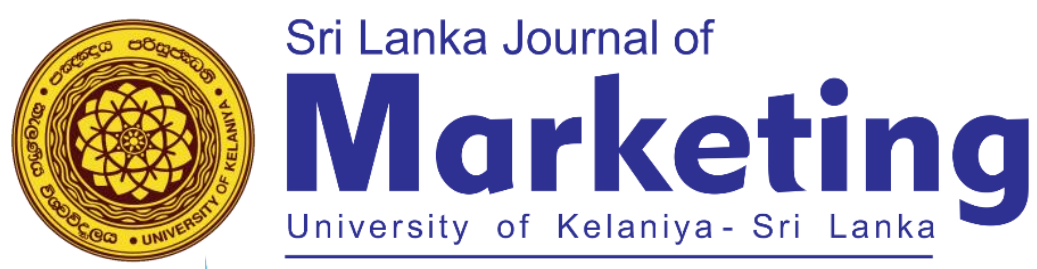

\title{
Study on Attitude towards Green Products and Willingness to Pay Premium: With Special Reference to Millenials in Sri Lanka.
}

\begin{tabular}{|c|}
\hline Wathsala Niwarthana \\
University of Peradeniya, Sri Lanka \\
wathsalaniwarthana@gmail.com \\
Sachini Gannoruwa \\
University of Peradeniya, Sri Lanka \\
sachinigannoruw@ gmail.com \\
R.M.U.R.K. Rathnayaka \\
University of Peradeniya, Sri Lanka \\
udayanganimkt@pdn.ac.lk \\
\hline
\end{tabular}

\section{ABSTRACT}

The concerns on green products and the green business practices has becoming one of the emerging areas in today's context. In relation to that, number of research studies have been conducted by different scholars in different settings. The purpose of this study was to study the impact made by the attitude towards the green products on the willingness to pay premium among the Millennials in Sri Lanka. Accordingly, the study intended to achieve four research objectives namely, to identify the impact made by attitude toward green products on willingness to pay premium, to measure the impact made by environmental concern on attitude toward green products, to identify the impact made by collectivism on attitude toward green products and to evaluate the impact of interpersonal influence on attitude toward green products among the millennials in Sri Lanka. A sample of 200 young adults has been selected on convenience sampling technique under non probability sampling method. The Structural Equation Modelling was performed to analyses the data of the study and the regression analysis was used to test the hypotheses of the study. The study found that, the attitude towards the green products make a significant influence on the millennials in determining their willingness to pay premium and also it has found that, the environmental concern towards the attitude plays a major role in determining the willingness to pay premium on green products among millennials.

Keywords: Attitude towards Green Products, Collectivism, Environmental Concern, Interpersonal Influence, Willingness to Pay Premium. 


\section{INTRODUCTION}

With its holistic redefinition of the conventional business pathways, the concerns on the green products has emerged in today's contemporary business world in which, each and every firm is finding their ways and means to maximize their strategic objectives while minimizing the impact that they made towards the environment. Due to the environmental damage caused by the non-sustainable production practices which are implemented by the majority of the business firms, the authorities and the pressure groups have increased the influence toward the businesses who are engaged with the unhealthy business practices for the natural environment. Not only had that, due to the recent discussions arose among the society regarding the environment protection, the concern of the consumers towards the businesses who are involving environmental friendly business practices has increased. As a result of that majority of the successful business in today's context are trying to involve the environmental friendly business practices to their major business operations. Consequently, they have been able to create a favourable image in the consumer's mind toward their brand, products and the business as a whole (Ottman, 2008). Beyond the cut throat competition of gaining the mind share and the market share for their brands, it can be seen that today's marketer plays a vital role in creating a distinctive identity through the green concerns. Even though this is an emerging area in the real business world, it has become an overlooked area in the domain of research.

Green products are often associated with inconvenience, high costs, and lower performance (Chen and Chai 2010; Mainieri et al. 1997; Newman, Gorlin, and Dhar 2014; Ottman, Stafford, and Hartman 2006). Also it can be observed in the Sri Lankan consumer market that, the level of price towards the green products are comparatively high compared to the artificial products. Even though the price level is high, how far the attitude towards green products made them to pay premium on purchasing such products has become a question for the researchers. Thus, the purpose of the study is to study the impact made by the attitude towards the green products on the willingness to pay premium among the Millennials in Sri Lanka.

\subsection{Research Objectives}

The objectives which are expected to achieve from the study are as follows.

i. To examine the overall impact made by attitude toward green products on willingness to pay premium among the millennials in Sri Lanka

ii. To determine the impact made by environmental concern on attitude toward green products among the millennials in Sri Lanka

iii. To examine the impact made by collectivism on attitude toward green products among the millennials in Sri Lanka 
iv. To evaluate the impact of interpersonal influence on attitude toward green products among the millennials in Sri Lanka

\section{LITERATURE REVIEW}

Shamdasami et al., (1993) defined green product as the product that will not pollute the earth or deplore natural resources, and can be recycled or conserved. According to (Ajzen and Fishbein, 1980, p. 5), theory of reasoned action, "people consider the implications of their actions before they decide to engage or not engage in a given behaviour".

Roberts and Bacon, (1997) stated that a consumer's environmental attitudes and behaviour have been documented as a complex, yet vital concept required to address the profile of the ecologically conscious consumer. Further, as per Achchurthan (2017) suggests, consumers in the South Asian Region, possess a positive attitude towards buying green products and thereby provides a prior notice to the marketers, who are actively involved in the green business in the local and international markets.

When it comes to WTPP (Willingness to Pay Premium), attitudes are the most consistent explanatory factor in predicting consumers' willingness to pay for green products. (Chyong et al., 2006). Cheah and Phau (2011) found that consumers with favourable attitude towards environment were more inclined to pay a premium for green products. There is abundant evidence are showing that consumers are willing to pay a premium to "protect the environment" (Cairncross, 1992; cason and Gangadharan, 2001; Kirchchoff, 1990; Wasik, 1996)

Additionally, collectivism and environmental concern emerged as predictors of ATGP (Attitude towards Green Products). According to Wesely, "attitudes of environmental concern are rooted in a person's concept of self and the degree to which an individual perceives him or herself to be an integral part of the natural environment" (Schultz et al, 2000) and consumers' product purchasing decisions are often based on their environmental attitudes (Irland, (1993), Schwepker and Cornwell, (1991)

On the other hand, Millennials also known as Generation Y, identified as a generational group with strong opinions about green issues among all generational groups (Jang et al., 2011). Characterized as the largest generation of consumers Benckendorff et al., (2010) and Parment, (2013) has defined millennials/ Gen 'Y's as individuals who were born between the 1980s and late 1990s, reaching young adulthood in the early 21 st century. Millennials grew up in an electronics-filled and increasingly online and socially-networked world. They are the generation that has received the most marketing attention. As the most ethnically diverse generation, millennials tend to be tolerant of difference. Despite the fact that millennials have grown up in one of the most difficult economic climates, a global study (Nielsen 2015) found that this group continues to be most willing to pay extra for sustainable offerings. And also Tang and Lam, (2017) found that positive attitude towards green products can result in willingness to 
pay premium with special reference to Generation $\mathrm{Y}$ consumers in China. While some research regarding this group of consumers shows that being environmentally friendly is key to attracting their interest, and they seek brands they regard as having a positive effect on the environment (Henrichs 2008; Rosenburg 2015), some other studies suggest that millennials are more attitudinally green than behaviorally green (Diamantopoulos et al. 2003; Grønhøj and Thøgersen 2009; Johnson et al. 2004; Uyeki and Holland 2000). Some researches argue that almost three-out-of-four millennial respondents were willing to pay more for brands committed to a positive social and environmental impact, compared to only $51 \%$ of baby boomers (ages 50-64) willing to pay extra. (Imam Naderi and Eric Van Steenburg 2018) In addition, for those willing to spend more, personal values outweigh personal benefits, such as cost or convenience.

\section{RESEARCH METHODOLOGY}

The purpose of this research is descriptive and is conclusive in nature. Both primary and secondary sources of data have sourced for the study and it was conducted in the natural environment with minimal interference by the researchers. As the researchers want to find out the impact of attitude towards green products on willingness to pay premium, the data was collected in a natural or non-contrived setting. The data for this study was collected at a single point of time. Thus, the study is single cross-sectional. Millennial or Young Adults who were born in between 1980's late 1990's was the population for this study. A sample of 200 young adults has been selected on convenience sampling technique under non probability sampling method. The Structural Equation Modelling was used to analyse the data through the AMOS package.

The conceptual framework which has constructed based on the literature review is as follows.

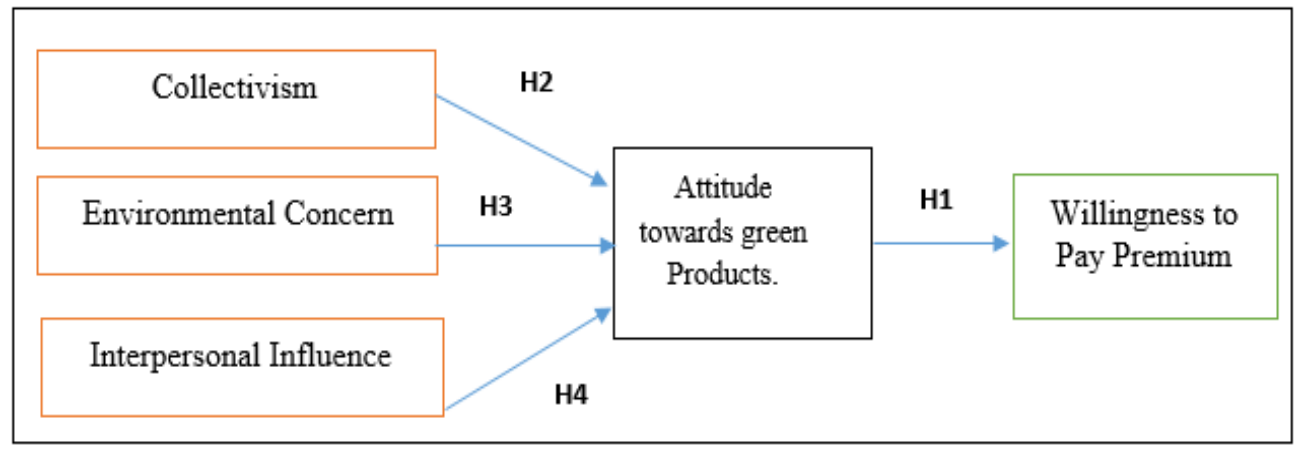

Source: Constructed Based on the Literature Review 


\subsection{Measures \& Hypotheses}

\subsubsection{Collectivism}

Collectivism is the conviction that focuses on interdependence, in-group harmony, family security, group-oriented goals, social hierarchies, cooperation and a low level of competition (Hofstede, 1980). In this study, three indicators have used to test this variable (Kirmani et al, 2017)

\subsubsection{Environmental Concern}

Environmental concern can be defined as the degree of consumer worry focusing on threats to environment and highlights their sensitivity to issues related to environment (Hassan, 2014). In this study, three indicators have used to test this variable (Kirmani et al, 2017)

\subsubsection{Interpersonal Influence}

Interpersonal influence primarily consists of the impact of acting to persuade, convince or influence others for the purpose of having a specific effect. An important determinant of an individual's behaviour is the influence of others (Bearden et al., 1989). In this study, three indicators have used to test this variable (Kirmani et al, 2017).

\subsubsection{Attitude towards Green Products}

Attitude represents predisposition to act positively or negatively towards specific objects related to and situations confronted by an individual (Allport, 1935; Blackwell et al., 2006; Moser, 2015). It should be noted that attitude is different from intention and behaviour. While intention is an indicator of readiness of an individual to perform a certain action, behaviour is the actual transition of intention of an individual into his/her action or practice (YadavandPathak, 2016). In line with the definition of attitude, ATGP reflects the consumer predisposition to act favourably or unfavourably towards green products (Kirmani and Khan, 2016). In this study, four indicators have used to test this variable (Kirmani et al, 2017)

\subsubsection{Willingness to Pay Premium}

Willingness to pay premium can be identified as the intention to purchase a specific product item by paying a premium price (Kirmani et al., 2017). In this study, three indicators have used to test this variable (Kirmani et al, 2017)

In line with the above conceptual model, the following hypotheses were developed based on the literature review.

H1: Attitude toward green products has a significant influence on willingness to pay premium 
H2: There is a significant impact of environmental concern on attitude toward green products

H3: There is a significant impact of collectivism on attitude toward green products

H4: There is a significant influence of interpersonal influence on attitude toward green products

\section{DATA ANALYSIS}

\subsection{Preliminary Analysis}

Prior to conduct the main analysis, a data examination has been conducted for the data set received by the sample respondents of the study. A missing value analysis has been conducted initially and confirmed that no missing values are presented in the dataset.

\subsection{Test of Normality}

A test of normality has been conducted to identify the outliers and to confirm the data set is normally distributed. Normality refers to the shape of the data distribution for an individual metric variable and its correspondent to normal distribution, the benchmark for statistical methods (Hair et al., 2010). In this study, the researcher used skewness and kurtosis values as statistical tests to assess the normality (Hair et al., 2010). Skewness defines the asymmetry of the probability distribution of a random variable about its mean, while the Kurtosis tells the height and sharpness of the central peak, relative to that of a standard bell curve (Field, 2005).

Table 1: Normality Test

\begin{tabular}{|l|l|l|}
\hline \multicolumn{1}{|c|}{ Variable } & \multicolumn{1}{c|}{ Skewness } & \multicolumn{1}{c|}{ Kurtosis } \\
\hline Collectivism & -0.315 & 0.419 \\
\hline Interpersonal Influence & -0.316 & -0.569 \\
\hline Environmental Concern & -0.404 & 0.959 \\
\hline Willingness to pay & -0.916 & 0.925 \\
\hline Attitude Toward Green Products & -0.661 & 0.825 \\
\hline
\end{tabular}

Source: Survey Data 2020

A skewness value of above 3 and kurtosis value of above 10 is indicative of those that depart from normality (Kline, 2011). Accordingly, the data set use for the current study has normally distributed and as a result of that, the parametric test can be applied. 


\subsection{Test of Adequacy of Sample}

In order to measure the sample adequacy, the Kaiser-Meyer-Olkin test has been conducted. The value of KMO should be in between 0 and 1 and the values greater than 0.5 are considered as acceptable (Kaiser and Rice, 1974).

Table 2: KMO and Bartlett's Test

Kaiser-Meyer-Olkin Measure of Sampling Adequacy.

Bartlett's Test of Sphericity

Approx. Chi-Square

.795

1159.267

df

Sig.

.000

The above table confirms that, the KMO value is $>0.5$ as acceptable. Therefore, it can be concluded that, the factor analysis is appropriate for the data set. Since the KMO test is highly significant $(\mathrm{p}<0.05)$ the factor analysis claims to be appropriate for further analysis.

\subsection{Model Fitness}

As depicted by Hair et al. (2010), it is required to analyze the Goodness of Fit (GOF) indices when assessing the fit of a measurement model. Accordingly, CMIN/DF, GFI, RMSEA, CFI, TLI and AGFI were identified as GOF indices when evaluate model fit.

Table 3: Model Fit Results

\begin{tabular}{|l|l|l|}
\hline Index & Value & $\begin{array}{l}\text { Acceptable scale for good and adequate fit (Hair } \\
\text { et al. (2010) }\end{array}$ \\
\hline CMIN/DF & 2.059 & $1-3$ \\
\hline RMSEA & 0.073 & Values between 0.05 \& 0.08 indicate adequate fit \\
\hline CFI & 0.908 & $\begin{array}{l}\text { Value between 0-1 (above 90) usually associated } \\
\text { with a model that fits well) }\end{array}$ \\
\hline PRATIO & 0.783 & Value between 0-1 (higher is better fit) \\
\hline TLI & 0.882 & $\begin{array}{l}\text { Value between 0-1 (models with good fit have values } \\
\text { that approach 1) }\end{array}$ \\
\hline
\end{tabular}

Since the minimum requirements of each index fulfilled, it is claims to be that the measurement model based for the current study is in a good level of fit. 


\subsection{Testing Validity \& Reliability}

\subsubsection{Test of Reliability}

The test of reliability provides an indication of internal reliability of the indicators which are used to measure the constructs (Hair et al., 2010).

Table 4: Test of Reliability

\begin{tabular}{|l|l|}
\hline \multicolumn{1}{|c|}{ Variable } & \multicolumn{1}{c|}{ CR } \\
\hline Collectivism (C) & 0.9168 \\
\hline Environmental Concern (EC) & 0.7008 \\
\hline Interpersonal Influence(II) & 0.6467 \\
\hline Attitude toward green products(ATGP) & 0.8061 \\
\hline Willingness to pay premium (WTP) & 0.8598 \\
\hline
\end{tabular}

(Source: Survey data, 2020)

The rule of thumb for analyze CR is, it should be 0.6 or higher. If the $\mathrm{CR}$ value is $>0.7$, the reliability is good with the internal consistency (Fornell and Bookstein, 1982). Accordingly, the above table shows that, the reliability for each factor shows that, there is a good internal consistency.

\subsubsection{Test of Validity}

In this, the Convergent validity was measured using the factor loading, composite reliability (CR) and the average variance extracted (AVE).

Table 5: Test of Validity

\begin{tabular}{|l|l|l|}
\hline \multicolumn{1}{|c|}{ Variable } & \multicolumn{1}{|c|}{$\begin{array}{c}\text { Sum of the squared } \\
\text { standardized loadings }\end{array}$} & AVE \\
\hline Collectivism (C) & 2.002475 & 0.6674 \\
\hline Environmental Concern (EC) & 1.049189 & 0.5913 \\
\hline Interpersonal Influence(II) & 1.119 & 0.6103 \\
\hline Attitude toward green products(ATGP) & 1.826238 & 0.5051 \\
\hline Willingness to pay premium (WTP) & 1.818932 & 0.6063 \\
\hline
\end{tabular}

(Source: Survey data, 2020)

As shown in the above table, the AVE values are greater than 0.5 and it provide an evidence of convergent validity of the study constructs. 


\subsection{Sample Profile}

The majority of the sample is represented by females and is $56.8 \%$ in percentage. When concern about the income level of the sample, $75.5 \%$ of respondents' income level belongs to $0-50,000$ category. The majority of the respondents' educational level belongs to category of Bachelor's degree which is $79.4 \%$.

\subsection{Hypotheses Testing}

In this study, there are four hypotheses which were constructed at the beginning of the study with the stage of literature review. Since the structural model had a good fit with the data, it supported the basic theoretical model of the study. In order to test the hypotheses, a regression analysis under Structural Equation Modelling has been conducted.

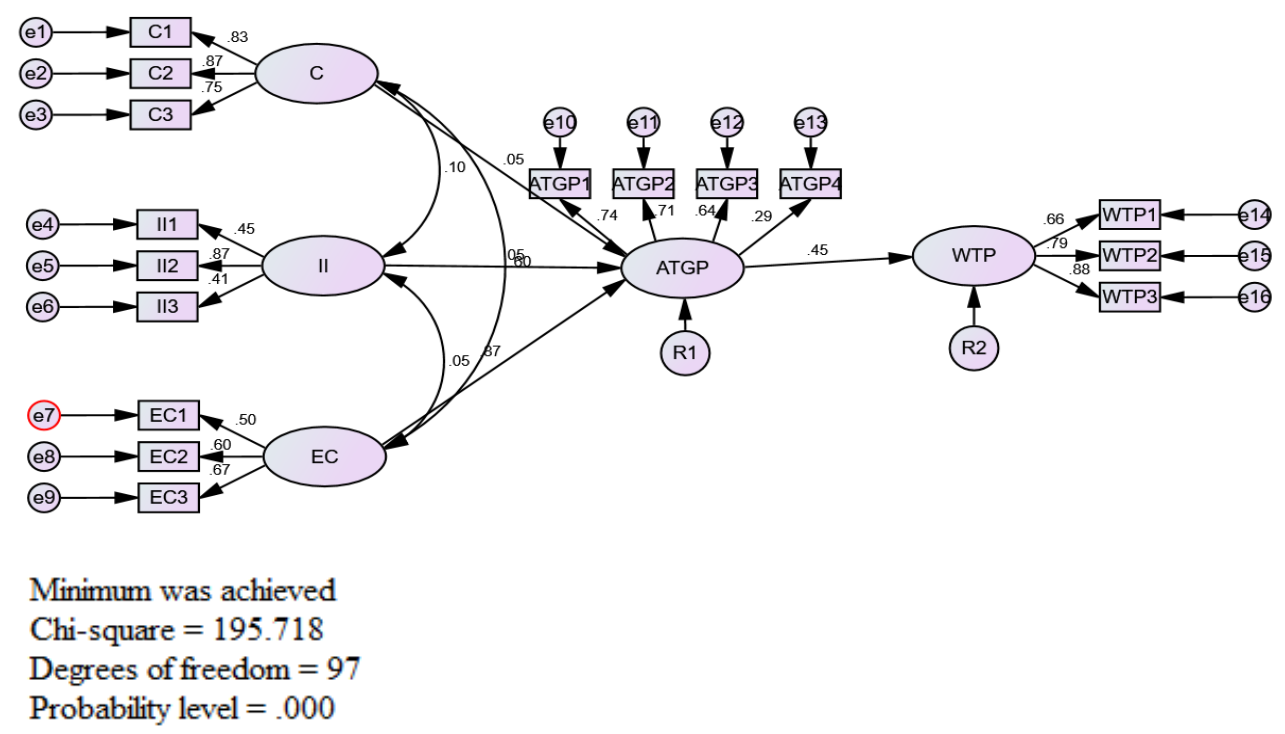

As per the structural model depicted above, four relationships are examined under four hypotheses as follows.

Table 6: Results of Hypotheses Test

\begin{tabular}{|l|l|l|l|l|}
\hline Path & Hypotheses & B & p-value & Result \\
\hline ATGP=>WTP & $\begin{array}{l}\text { H1: Attitude toward green products has a } \\
\text { significant influence on willingness to pay } \\
\text { premium }\end{array}$ & 0.454 & 0.000 & Supported \\
\hline C=>ATGP & $\begin{array}{l}\text { H2: There is a significant impact of } \\
\text { environmental concern on attitude } \\
\text { toward green products }\end{array}$ & 0.054 & 0.651 & Not Supported \\
\hline
\end{tabular}




\begin{tabular}{|l|l|l|l|l|}
\hline II=>ATGP & $\begin{array}{l}\text { H3: There is a significant impact of } \\
\text { collectivism on attitude toward green } \\
\text { products }\end{array}$ & 0.046 & 0.563 & Not Supported \\
\hline EC=>ATGP & $\begin{array}{l}\text { H4: There is a significant influence of } \\
\text { interpersonal influence on attitude } \\
\text { toward green products }\end{array}$ & 0.870 & 0.000 & Supported \\
\hline
\end{tabular}

\section{CONCLUSION}

A representative sample of 200 millenials in Sri Lanka were selected based on the convenience sampling technique for this study. A self-administered questionnaire has used for the study as the main data collection instrument. The study aimed at testing for four relationships subjected to four hypotheses mainly. According to the hypotheses test result, two hypotheses (H1 \& H4) were accepted out of the four hypotheses formulated at the beginning of the study. As per the study findings, it is evidenced that, the attitude towards the green products make a significant influence on the millenials in determining their willingness to pay premium. Further, it has found that, the environmental concern towards attitude plays a major role in determining the willingness to pay premium towards green products among millenials which supports the findings of previous studies (Tang et al., 2014; Kirmani and Khan, 2018). Based on the study findings it can be concluded that the attitude of the millenials towards the green products play a significant role in willingness to pay premium.

\section{DISCUSSION ON MANAGERIAL IMPLICATIONS AND FUTURE RESEARCH DIRECTIONS}

This study significantly contributes in the understanding of the complex relationships among the study variables such as collectivism, environmental concern, and willingness to pay premium, which are less explored in Sri Lankan context. Further, study revealed that environmental concern towards the attitude plays a major role in determining the attitude towards green products.

Since this study was referenced to the millenials in Sri Lanka, it is very important to incorporate the common characteristics of these generation when interpreting the findings of the study. In general, millenials are considered as the curious generation which valued individualism and the financial stability (Tang et al., 2017). It is evidenced from the study findings that, the impact of interpersonal influence and the collectivism factor of the individuals do not make an impact on forming an attitude toward the green products. Thus the only factor which make them willingness to purchase green products is the concern about the environment. Since the millenials are considered to be tech savvy type of generation, they are informative and highly knowledgeable in terms of the asymmetry of the 
information availability. So it is the marketers' responsibility to attract the millenials, making an interest towards the green products, and to make them willingness to purchase the green products by forming a favourable attitude towards the green products. In that sense, number of opportunities are available for the marketers to reach the millenials such as social media sources. It is highly important task to communicate millenials a logical reason associated with the concern on environment, which make them purchase the green products.

As the recommendations for further researchers, it is suggested that they can be concentrated on studying the other factors such as product quality, Brand image and etc. which may influence on millenials' willingness to pay premium. Moreover, further studies are encouraged to replicate the same model by considering another consumer groups like Generation X, professionals etc.

\section{REFERENCES}

[1] Bearden, W.O., Netemeyer, R.G. \& Teel, J.E. (1989). Measurement of consumer susceptibility to interpersonal influence. Journal of Consumer Research, 15(4), pp.473-481.

[2] Benckendorff, P., Moscardo, G., \& Murphy, L. (2012). Environmental attitudes of Generation Y students: Foundations for sustainability education in tourism. Journal of Teaching in Travel \& Tourism, 12(1), pp.44-69.

[3] Bessley, M., \& Wilson, P. (1984). Small Business Theory and Policy. London: Croom Helm, pp.111-126.

[4] Casson, M. (1979). Alternatives to the multinational enterprise. Springer.

[5] Cheah, I., \& Phau, I. (2011). Attitudes towards environmentally friendly products: The influence of ecoliteracy, interpersonal influence and value orientation. Marketing Intelligence \& Planning, 29(5), pp.452-472.

[6] D'Souza, C., Taghian, M., \& Lamb, P. (2006). An empirical study on the influence of environmental labels on consumers. Corporate communications: an international journal, 11(2), pp.162-173.

[7] Hasnah Hassan, S. (2014). The role of Islamic values on green purchase intention. Journal of Islamic Marketing, 5(3), pp.379-395.

[8] Gregory, S. (1982). Culture's Consequences: International Differences in Work-Related Values: G. Hofstede Sage Publications, Beverly Hills, CA, USA (1980) 475 pp18-75.

[9] Jang, Y.J., Kim, W.G. \& Bonn, M.A. (2011). Generation Y consumers' selection attributes and behavioural intentions concerning green restaurants. International Journal of Hospitality Management, 30(4), pp.803-811.

[10] Kinnear, T.C., Taylor, J.R., \& Ahmed, S.A. (1974). Ecologically Concerned Consumers: Who are They? Ecologically Concerned Consumers can be Identified. Journal of Marketing, 38(2), pp.2024. 
[11] Laroche, M., Bergeron, J., \& Barbaro-Forleo, G. (2001). Targeting consumers who are willing to pay more for environmentally friendly products. Journal of Consumer Marketing, 18(6), pp.503520.

[12] McCarty, J.A., \& Shrum, L.J. (1994). The recycling of solid wastes: Personal values, value orientations, and attitudes about recycling as antecedents of recycling behavior. Journal of Business Research, 30(1), pp.53-62.

[13] Kirmani, M.D., \& Khan, M.N. (2018). Decoding willingness of Indian consumers to pay a premium on green products. South Asian Journal of Business Studies, 7(1), pp.73-90

[14] Parment, A. (2013). Generation Y vs. Baby Boomers: Shopping behaviour, buyer involvement and implications for retailing. Journal of Retailing and Consumer Services, 20(2), pp.189-199.

[15] Roberts, J.A., \& Bacon, D.R. (1997). Exploring the subtle relationships between environmental concern and ecologically conscious consumer behaviour. Journal of Business Research, 40(1), pp.79-89.

[16] Shamdasani, P., Chon-Lin, G.O., \& Richmond, D. (1993). Exploring green consumers in an oriental culture: role of personal and marketing mix factors. ACR North American Advances.

[17] Tang, C.M.F., \& Lam, D. (2017). The role of extraversion and agreeableness traits on Gen Y's attitudes and willingness to pay for green hotels. International Journal of Contemporary Hospitality Management, 29(1), pp.607-623.

[18] Tsen, C.H., Phang, G., Hasan, H., \& Buncha, M.R. (2006). Going green: A study of consumers' willingness to pay for green products in Kota Kinabalu. International Journal of Business and Society, 7(2), pp.40-54. 